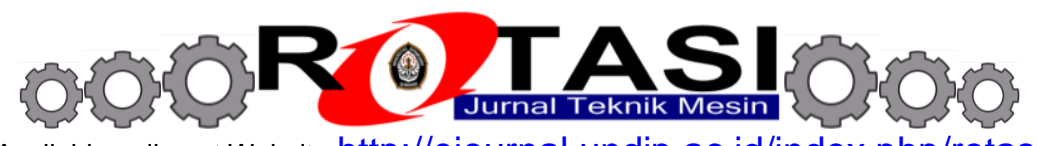

Available online at Website http://ejournal.undip.ac.id/index.php/rotasi

\title{
KEGAGALAN FUNGSI PENGEREMAN BIS DAN TRUK AKIBAT RUSAKNYA KOMPONEN RAKITAN KAMPAS REM
}

\author{
*Dwi Basuki Wibowo, Ismoyo Haryanto \\ Jurusan Teknik Mesin, Fakultas Teknik, Universitas Diponegoro \\ Jl.Prof.Sudarto, Tembalang, Semarang, Indonesia \\ *E-mail: rmt.bowo@gmail.com
}

\begin{abstract}
ABSTRAK
Federal Motor Vehicle Safety Standard (FMVSS) mengklasifikasikan kendaraan bis dan truk (trailer dan container) sebagai heavy duty vehicle dimana rem, kopling, dan ban adalah komponen-komponen yang harus diperiksa secara rutin karena berkaitan dengan keamanan dan umur pemakaiannya yang relatif pendek. Sebagai komponen utama material gesek kampas rem memang harus bagus dan harus lolos serangkaian test sebagaimana diatur dalam berbagai standard yaitu SNI 09-0143-1987, ASTM G0115-04, ASTM D3359-02. Tetapi menurut The American Public Transportation Association (APTA BTS-SS-RP-003-07), kinerja sistim pengereman bis dan truk tidak semata-mata ditentukan oleh kualitas material kampas rem saja tetapi juga oleh kondisi brake shoe dan prosedur pemasangan (rebuild) kampas pada brake shoe. Dari hasil survey banyak pengusaha transportasi bis di Indonesia yang mengabaikan prosedur rebuild kampas rem yang telah distandarkan oleh APTA BTS-SS-RP003-07 tersebut. Akibatnya kampas rem cepat aus, rem terkunci, dan yang paling parah adalah rem blong (rem tidak berfungsi). Fokus utama penelitian ini adalah mengkaji kemungkinan kerusakan brake shoe assembly (komponen rakitan kampas rem) saat pengereman yang berpotensi menyebabkan terjadinya kegagalan fungsi pengereman pada bis/truk.
\end{abstract}

Kata kunci: APTA, bis, kampas rem, Rebuild, rem blong, truk

\section{PENDAHULUAN}

Kampas rem adalah komponen utama yang harus diperiksa secara rutin karena berkaitan dengan keamanan dan umur pemakaiannya yang relatif pendek. Dari hasil survey pelumas industri di Jawa Tengah dan Jawa Timur pada tahun 2006 - 2008 yang juga mengamati perawatan dan perbaikan komponen bis dan truk [1,2], terlihat banyak pengusaha transportasi di Indonesia melakukan rebuild (mengganti dan memasang) kampas rem sendiri tidak mengikuti prosedur yang telah distandarkan oleh APTA BTS-SS-RP-003-07 [3]. Akibatnya kampas rem cepat aus yang beresiko tinggi terjadinya kecelakaan karena rem terkunci atau "rem blong" (rem tidak berfungsi).

Meskipun angka pasti kecelakaan lalu lintas yang diakibatkan oleh bus dan truk setiap tahunnya belum tersedia di Kepolisian/Dinas Perhubungan Darat, tetapi berita-berita di media menunjukkan kejadian tersebut cukup banyak yang diantaranya disebabkan oleh rem blong. MTI (Masyarakat Transportasi Indonesia) mencatat pada tahun 2007 terjadi kecelakaan kendaraan bermotor (termasuk bis dan truk) di jalan raya sebanyak 48,508 kasus, tahun 2008 terjadi 59,264 kasus dan tahun 2009 meningkat menjadi 62,960 kasus [4]. Peluang terjadinya kecelakaan ini bisa semakin banyak karena fakta menunjukkan jumlah kendaraan bis dan truk yang lalu lalang di jalan raya sejak tahun 2007 - 2011 terus meningkat, masing-masing sebesar $11.29 \%$ dan $8.16 \%$ (tahun 2011 jumlah bis mencapai 2,254,406 unit dan truk 4,958,738 unit) [5].

Hasil pengamatan Diskominfo rem blong bis dan truk di Indonesia umumnya disebabkan oleh oli rem habis, diantaranya pada kasus-kasus :

1) Kecelakaan rem blong bus PO. Nugroho di turunan Jl. Dr. Wahidin Semarang 3 Mei 2013 yang menabrak 4 mobil dan sejumlah sepeda motor dan menewaskan 3 orang (Sumber: Koran Suara Merdeka 4 Mei 2013).

2) Kecelakaan rem blong bus PO. Karya Sari di Pageralang Kemranjen Banyumas Jawa Tengah 10 Agustus 2013, menewaskan 15 orang dan puluhan orang luka-luka (Sumber: Koran Suara Merdeka 11 Agustus 2013).

3) Kecelakaan rem blong bus Pariwisata PO. Giri Indah di Cisarua, Bogor pada 21 Agustus 2013 yang menewaskan 16 orang (Sumber: Koran Suara Merdeka 22 Agustus 2013).

4) Kecelakaan rem blong truk tronton bermuatan pasir besi di pasar Babadan Ungaran Kab. Semarang pada 24 Sept 2013 yang menabrak 5 mobil dan 2 sepeda motor dan menewaskan 2 orang dan 11 orang luka ringan (Sumber: Koran Suara Merdeka 25 September 2013).

Habisnya oli rem ini bisa disebabkan oleh banyak faktor yaitu seal master cylinder longgar karena usia atau kualitasnya yang tidak bagus, menguapnya oli rem karena kenaikan suhu kampas rem akibat frekuensi pengeremannya yang tinggi [6], pipa oli rem pecah/retak, dan brake shoe assembly rusak yang menyebabkan rem terkunci dan akhirnya tidak berfungsi sama sekali karena terjadi peningkatan tekanan oli dan suhu secara drastis saat pengereman. Semua ini bisa diketahui dengan pasti bila dilakukan investigasi mendetil seperti yang dilakukan KNKT saat meneliti penyebab kasus-kasus kecelakaan rem blong atas permintaan Dinas Perhubungan Darat. 
1) Bus Limas masuk jurang, jembatan Cikundul, Puncak, Cianjur, Jawa Barat tanggal 7 Juli 2007. Jumlah korban 16 orang meninggal dunia, 28 orang luka parah, dan 14 orang luka ringan [7].

2) Tabrakan antara bus pariwisata Fajar Transport dengan mobil Feroza di ruas jalan Cijambe, Kabupaten Subang, Jawa Barat, 29 Juli 2007. Jumlah korban 8 orang meninggal dunia dan 5 orang luka ringan [7].

Untuk kendaraan dengan beban berat dan/atau kecepatan relatif tinggi, kondisi lalin yang padat dan banyak jalan yang menurun dan menikung, seperti di Indonesia, menyebabkan tingginya frekuensi pengereman kendaraan. Hal ini mengakibatkan umur kampas rem menjadi lebih pendek. Rata-rata 2 minggu sekali kampas rem bus yang beroperasi di jalan raya antar kota atau antar propinsi harus diganti karena aus (private communication Dwi Basuki Wibowo dengan pengusaha bus Sumber Alam Kutoarjo Jateng).

Tingginya frekuensi penggantian kampas rem ini berkorelasi dengan pengeluaran anggaran yang besar yang harus disediakan oleh pengusaha angkutan bus/truk. Jika diambil harga rata-rata kampas rem asli (produksi luar negeri/OEM: Original Equipment Manufacturer) per-buah Rp. 225.000,- untuk roda depan dan Rp. 375.000,- untuk roda belakang (harga kampas rem asli untuk bis bervariasi antara Rp. 150.000,- s/d Rp. 400.000,- bergantung tipe dan merek kendaraan, private communication Dwi Basuki Wibowo dengan pengusaha Toko Lancar Jaya - Pasar Johar Semarang) dan jumlah roda setiap jenis kendaraan 4 buah, nilai uang yang dibelanjakan oleh pengusaha angkutan bis di Indonesia tahun 2011 mencapai Rp. 5.5 triliun/bulan. Untuk menghemat anggaran pengusaha transportasi bus/truk menggunakan kampas rem tidak asli (produksi dalam negeri/Non-OEM) yang harganya berkisar 1/3 dari harga kampas rem OEM, yaitu Rp. 75.000,-/unit untuk roda depan dan Rp. 125.000,-/unit untuk roda belakang.

Penggunaan kampas rem Non-OEM ditambah dengan proses rebuild yang tidak mengikuti prosedur yang telah distandarkan ini berpeluang besar terjadinya kegagalan fungsi pengereman. Atas dasar itu penelitian ini dilakukan.

\section{TUJUAN DAN MANFAAT PENELITIAN}

Penelitian ini bertujuan untuk mengkaji peluang terjadinya kerusakan sub-assembly kampas rem pada bis/truk. Ada 3 komponen sub-assembly kampas rem yang dikaji di sini yaitu : (1). kampas rem, (2). keling (rivet) pengikat kampas dengan brake shoe, (3). rangka rem (brake shoe) berdasar pada hipotesa kekuatan masing-masing komponen sebagai berikut : kekuatan brake shoe > keling > kampas rem. Penelitian ini juga bertujuan mengkaji langkah-langkah sebelum dilakukan penggantian dan pemasangan kembali dengan kampas rem baru, untuk mencegah terjadinya kegagalan fungsi pengereman.

Penelitian ini diharapkan bermanfaat bagi:

1) Tenaga mekanik perusahaan transportasi bis/truk maupun para pengrajin rebuild kampas rem dalam melakukan rebuild kampas rem.

2) Pengusaha transportasi bis/truk dalam menghemat biaya perawatan dan perbaikan sub-assembly rem.

3) Pemerintah (Dinas Perhubungan Darat dan Diskominfo) dalam mengurangi jumlah kecelakaan yang melibatkan bis dan truk karena kegagalan fungsi pengerman.

\section{TINJAUAN PUSTAKA}

Rem pada bis umumnya berbentuk rem drum (tromol) [8, 9], seperti diperlihatkan pada Gambar 1. Penyambungan antara kampas rem dan rangka rem disatukan menggunakan sambungan keling, yang terbukti pada temperatur tinggi dapat mengurangi transfer panas pada rangka rem dibandingkan sambungan lem (lihat Gambar 2) [9].

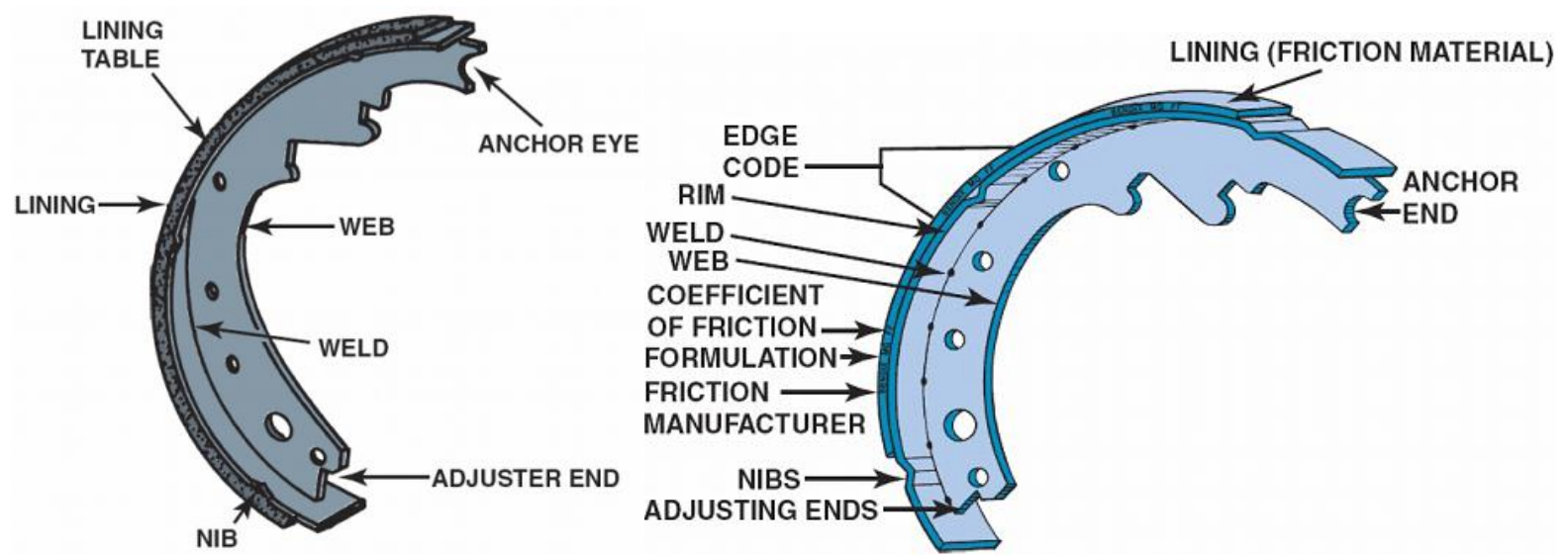

Gambar 1. Sepatu rem drum dan nama-nama bagiannya 

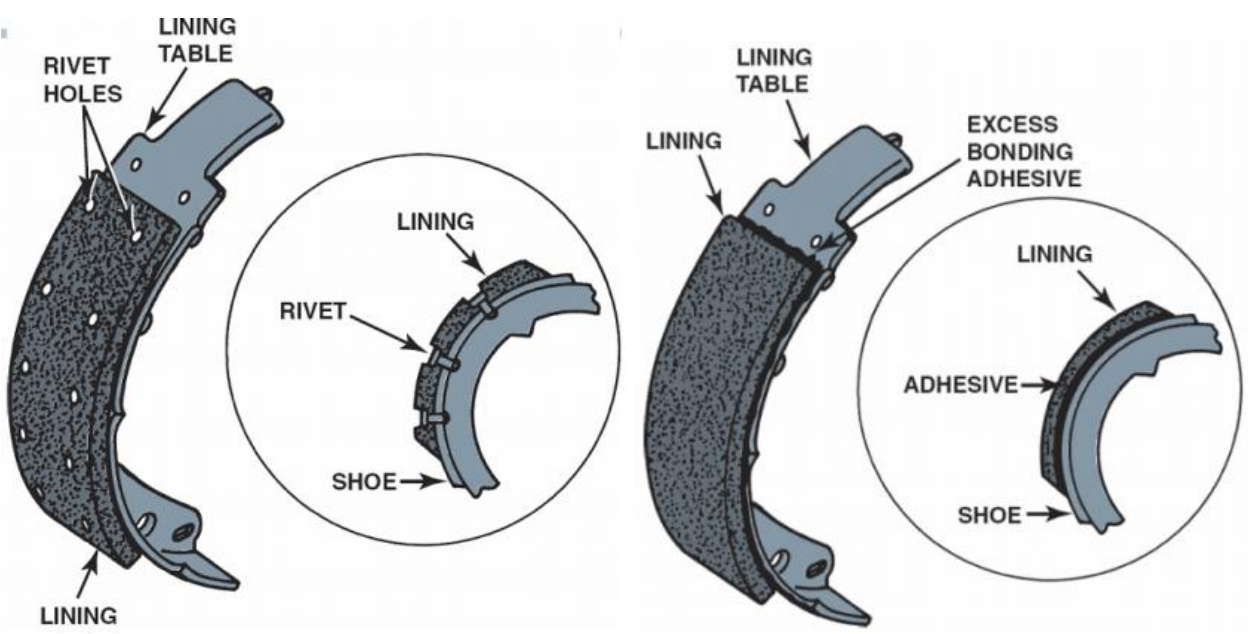

Gambar 2. Penyambungan sepatu rem menggunakan keling

Sebagai komponen utama material gesek kampas rem memang harus bagus dan harus lolos serangkaian test sebagaimana diatur dalam berbagai standard berikut ini:

1) SNI 09-0143-1987 yang meliputi uji koefisien gesek, uji kekerasan, uji tekan [10].

2) ASTM G0115-04 Guide for Measuring and Reporting Friction Coefficients [10].

3) ASTM D3359-02 Test Methods for Measuring Adhesion by Tape Test [10].

4) Original equipment vehicle manufacturer (OEM) manuals and catalog [10].

Tetapi dari hasil penelitian ternyata terbukti koefisien gesek bukanlah satu-satunya penentu kinerja pengereman karena semakin tinggi temperatur nilai koefisien geseknya semakin turun, seperti diperlihatkan pada Gambar 3 [12].

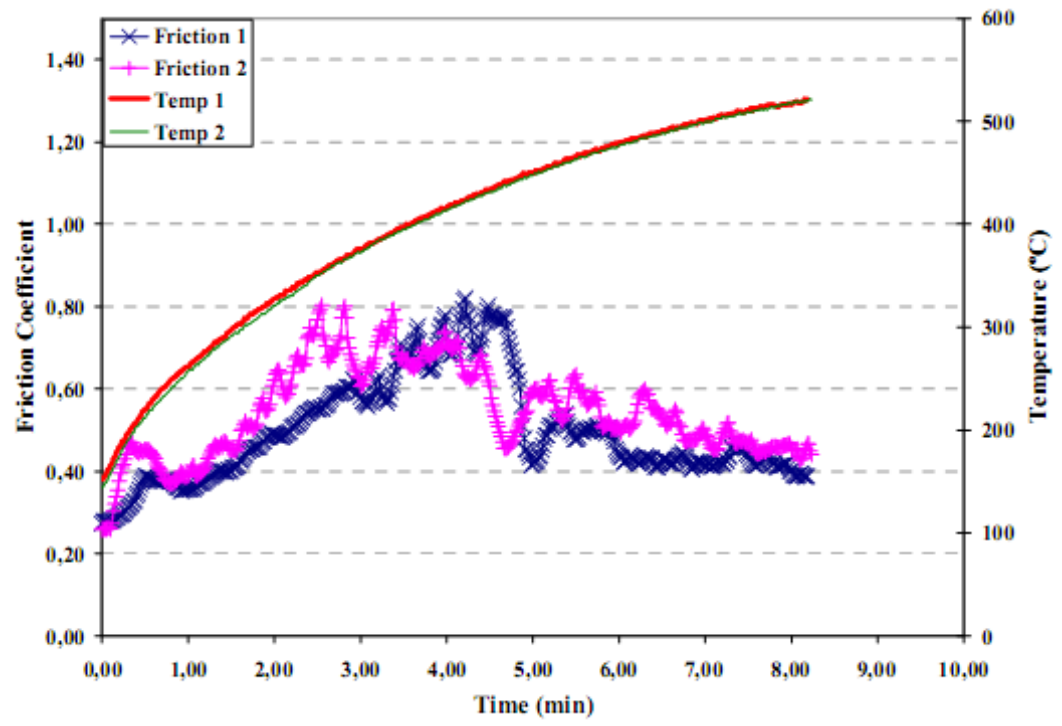

Gambar 3. Kurva temperatur dan koefisien gesek selama fase fading

Selain harus lolos test laboratorium, pemasangan kampas rem pada rangkanya juga harus benar dan menggunakan komponen-komponen yang standard. Berbagai standard berikut berkaitan dengan pemasangan kampas rem dan standard pengujiannya.

1) APTA BTS-SS-RP-003-07 Recommended Practice for Transit Bus Brake Shoe Rebuild [3].

2) ASTM A0502-03 Specification for Rivets, Steel, Structural [13].

3) APTA BT-RP-001-05 prosedur pengetesan kampas rem melalui uji jalan [14,15].

Menurut rekomendasi APTA BTS-SS-RP-003-07 tidak maksimalnya kinerja kampas rem tidak semata-mata disebabkan oleh kualitas kampas, tetapi juga bisa disebabkan oleh tidak dilakukannya pemeriksaan cacat dan perubahan bentuk dan dimensi rangka rem sebelum dilakukan pemasangan kampas rem baru. Rangka rem yang sudah berubah bentuk karena tekanan bisa menyebabkan kampas rem tidak "duduk" dengan rata (properly mate with the shoe table), yang selain berakibat kampas rem aus lebih cepat juga bisa menimbulkan keretakan pada kampas rem. Hal yang sama juga bisa terjadi bila pemasangan kampas rem pada rangkanya dengan paku keling yang tidak di-press dengan baik dan benar [3]. 


\section{PENGUJIAN KEKUATAN KELING DAN KAMPAS REM}

Kendaraan yang dijadikan sampel dalam penelitian ini adalah bis Mercedes Benz - OM 160 dengan type brake shoes 3054200519 dan kampas remnya (brake lining/brake block) menggunakan Frasle MB/184 buatan Italia seperti nampak pada Gambar 4 [16]. Material keling sebagai pengikat kampas rem dengan brake shoe adalah kuningan (brass) dengan yield strength $302.403 \mathrm{MPa}$ dan berdimensi sesuai spesifikasi yang distandarkan oleh ASTM A0502-03 [13] atau SAE J 660 [3], seperti nampak pada Gambar 5 dan Tabel 1.

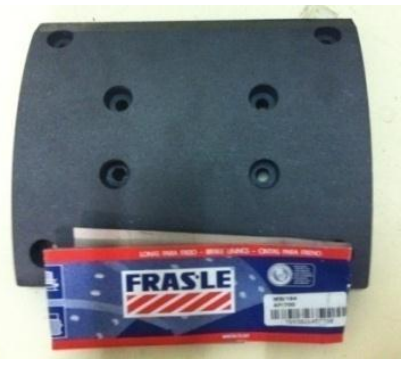

Diameter drum: $410 \mathrm{~mm}$

Lebar kampas: $160 \mathrm{~mm}$

Panjang kampas: $178 \mathrm{~mm}$

ATebal kampas: $17.3 \mathrm{~mm}$

\#

Jumlah lubang keling: 8, Diameter keling: $10 \mathrm{~mm}$

Gambar 4. Kampas rem bis merek Frasle
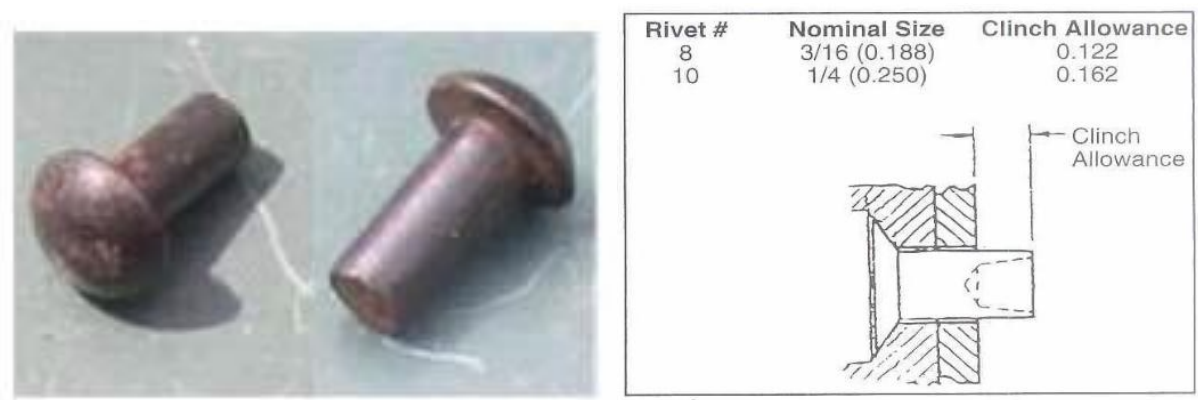

Gambar 5. Keling dan dimensinya menurut standar SAE J 660

Tabel 1. Dimensi paku keling untuk brake block berdasar SAE J 660 [3]

\begin{tabular}{|l|c|c|c|}
\hline Rivet Number & $\# 10$ & $\# 20$ & $3 / 8$ \\
\hline Rivet Shank Diameter, nominal & $0.250 "$ & $0.200 "$ & $0.375 "$ \\
\hline Clinch allowance & $0.162 "$ & $0.162 ”$ & $0.218 ”$ \\
\hline Diameter of hole in shoe & $17 / 64 "$ & $14 / 64 ”$ & $25 / 64 ”$ \\
\hline Rivet Length in increments of & $1 / 16 "$ & $1 / 16 ”$ & $1 / 16 "$ \\
\hline
\end{tabular}

\section{Pengujian Kekuatan Keling}

Metode pengujian keling mengacu pada prosedur yang telah distandarkan oleh ASTM D732 seperti nampak pada Gambar 6 [13]. Untuk mengetahui batas kemampuan keling menerima beban geser digunakan plat baja St 37 yang memiliki yield strength lebih tinggi dari pada kuningan. Hasil pengujian menunjukkan setiap keling mampu menahan beban geser sebesar $4.9 \times 10^{9} \mathrm{~N}$ [17].
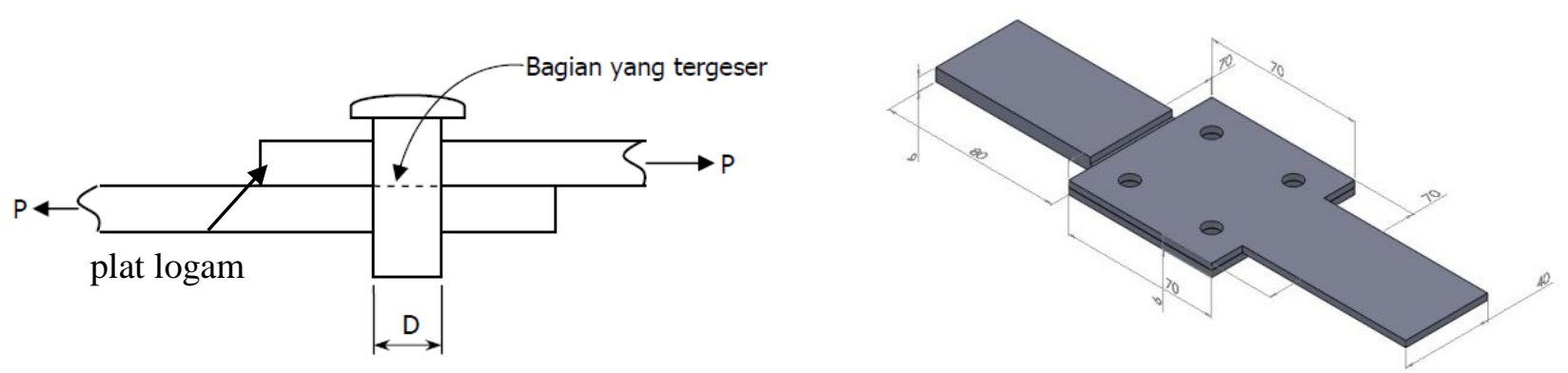

Gambar 6. Skematik pengujian geser keling dan dimensi plat baja untuk pengujian 


\section{Pengujian Kekuatan Kampas Rem}

Pengujian kampas rem menahan beban geser mengunakan kampas rem frasle MB/184, brake shoes type 3054200519 dengan metode pengujian mengacu pada standar ASTM D3359-02 [13], seperti nampak pada Gambar 7, dan alat bantu tekan seperti nampak pada Gambar 8.
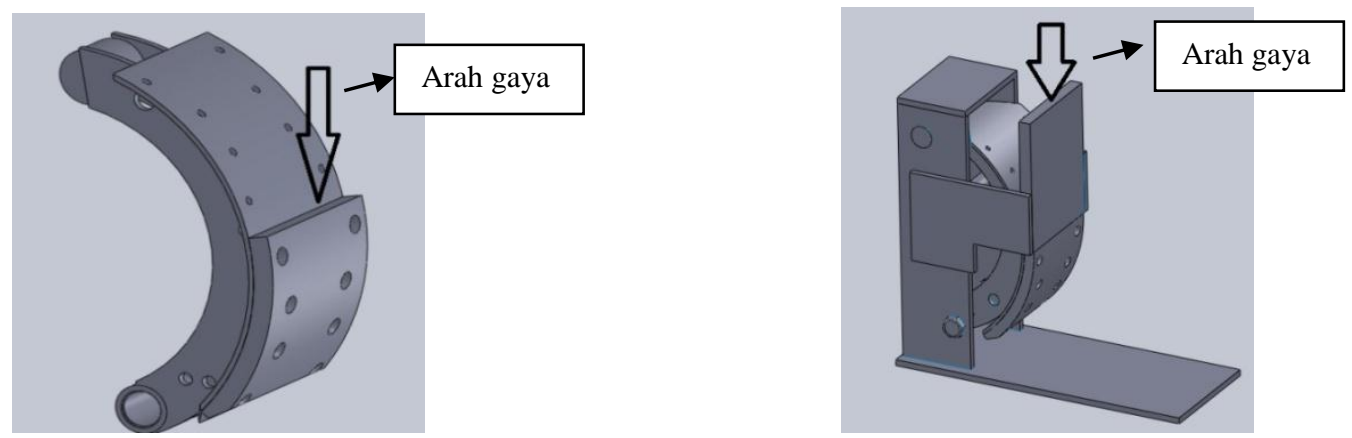

Gambar 7. Metode uji geser kampas rem menerima beban geser

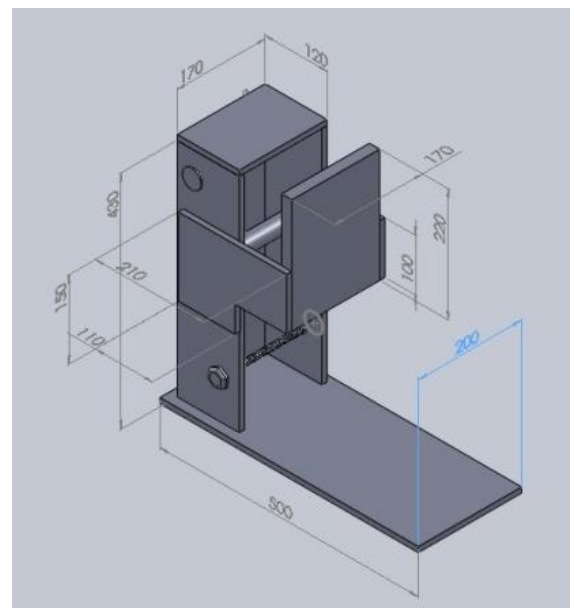

Gambar 8. Dimensi alat bantu tekan

Hasil pengujian pada assembly kampas rem diperoleh kemampuan maksimal kampas rem dalam menerima beban geser adalah sebesar 13.1 x 109 $\mathrm{N}$ [17]. Gambar 9 menunjukkan setelah dilakukan pengujian kampas rem robek, yang diawali dengan melebarnya lubang keling.

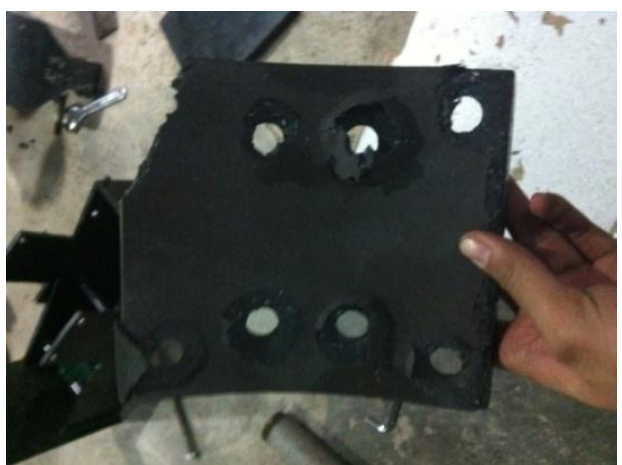

Gambar 9. Kerusakan kampas rem setelah dilakukan uji geser

\section{Kesimpulan}

Hasil pengujian kekuatan geser keling total (pada rakitan kampas rem terdapat 8 buah keling) adalah sebesar $39.1 \times 10^{9} \mathrm{~N}$ sedangkan kemampuan kampas rem dalam menerima beban geser yaitu sebesar $13.1 \times 10^{9} \mathrm{~N}$. Karena assembly kampas rem menggunakan 8 buah keling, maka beban geser yang diterima setiap keling pada kondisi pembebanan yang menyebabkan kampas rem rusak adalah sebesar $1.64 \times 10^{9} \mathrm{~N}$.

Dengan demikian dapat di simpukan bahwa beban yang menyebabkan kampas rem rusak sebesar 1/3 dari kemampuan keling dalam menerima beban geser. 


\section{KERUSAKAN BRAKE SHOE DAN PEMERIKSAANNYA}

Pemeriksaan brake shoe seyogyanya dilakukan sebelum mengganti dan memasang kampas rem baru. Prosedur pemeriksaan ini telah distandarkan oleh APTA BTS-SS-RP-003-07 yang meliputi : pengechekan peregangan pada brake shoe, kerataan permukaan brake shoe, kerusakan web, kelengkungan brake shoe, ketebalan brake shoe, kelonggaran lubang-lubang paku keling, keretakan las antara table dan web, dudukan roller dan kondisi roller, dan kondisi engsel/pin pegas pengembali ${ }^{[3]}$.

Seluruh hasil pengechekan kondisi brake shoe assembly tersebut dicatat dan bila kondisinya sudah tidak memungkinkan dipasang dengan kampas rem baru, segera dilakukan peggantian brake shoe baru.

1) Pengecekan Peregangan Brake Shoe (lihat Gambar 10)

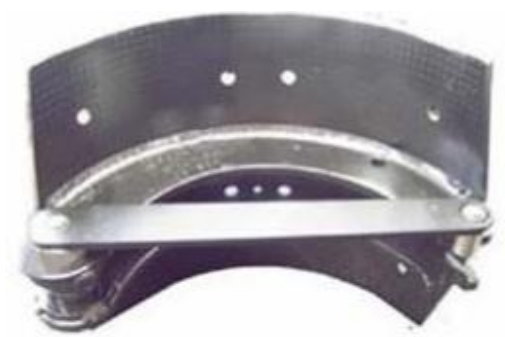

Jika bagian ujung terkecil gauge tidak fit dengan roller cup, brake shoe harus diganti

Gambar 10. Mengukur peregangan brake shoe menggunakan stretch gauge

2) Pengecekan Kerataan Permukaan Brake Shoe (lihat Gambar 11)

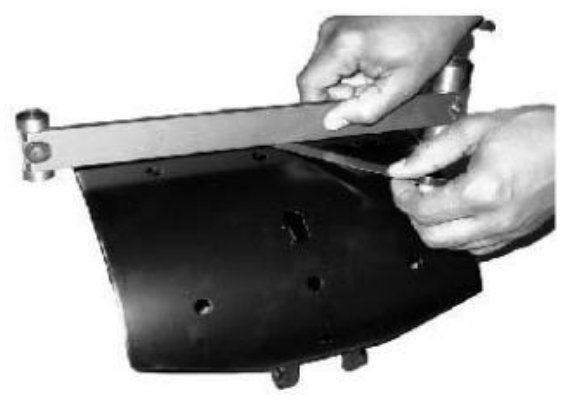

a) Ganti brake shoe apabila antara sisi terluar brake shoe dan straight edge dapat disisipkan 0.010 inch feeler gauge

b) Ganti brake shoe apabila antara pusat sumbu brake shoe dan straight edge dapat disisipkan 0.025 inch feeler gauge

Gambar 11. Mengechek kerataan permukaan brake shoe

3) Pengecekan Kerusakan Web (lihat Gambar 12)

Jarak antara web dan jarak antara the ears anchor pin end tidak boleh lebih dari jarak yang tertera pada Tabel 2 berikut.

Tabel 2. Shoe table web tolerances for stamped steel shoes

\begin{tabular}{|c|c|c|}
\hline $\begin{array}{c}\text { Brake size } \\
\text { Inches }\end{array}$ & $\begin{array}{c}\text { Maximum inner distance } \\
\text { between webs on cam end }\end{array}$ & $\begin{array}{c}\text { Maximum outer distance between webs } \\
\text { on anchor end }\end{array}$ \\
\hline $14.5 \times 6 \mathrm{~W}$ & $0.855^{\prime \prime}$ & $1.970 "$ \\
\hline $14.5 \times 10 \mathrm{~W}$ type 1 and 3 & $1.395^{\prime \prime}$ & $2.167 "$ \\
\hline $14.5 \times 10 \mathrm{~W}$ type 2 & $1.520 "$ & $2.914 "$ \\
\hline 15 and 16.5 Q-Plus & $1.550 "$ & $1.550 "$ \\
\hline
\end{tabular}

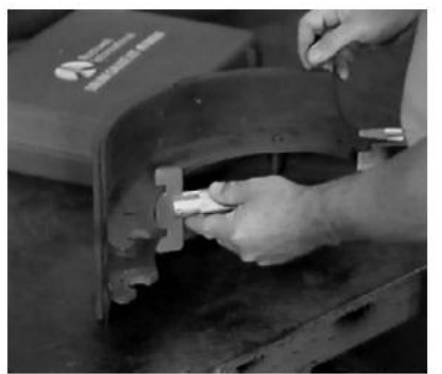

Gambar 12. Mengukur kerusakan web 
4) Pengecekan Kelengkungan Brake Shoe (lihat Gambar 13)

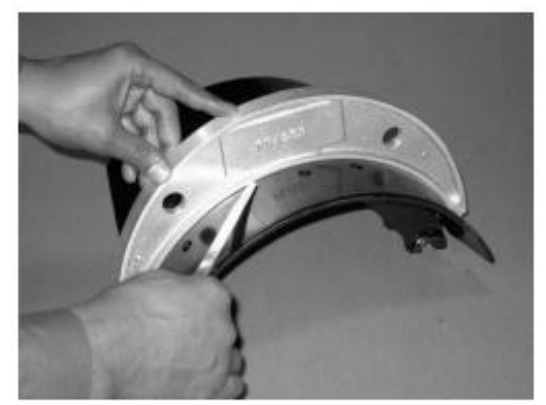

Sisipkan feeler gauge 0.030 inch antara shoe table dan arc gauge. Apabila feeler gauge 0.030 inch masih dirasa longgar, ganti brake shoe

Gambar13. Mengechek kelengkungan brake shoe menggunakan table arc gauge

5) Pengecekan Ketebalan Brake Shoe (Lihat Gambar 14 dan Tabel 3) Apabila gauge dapat digeser dengan mudah, ganti brake shoe

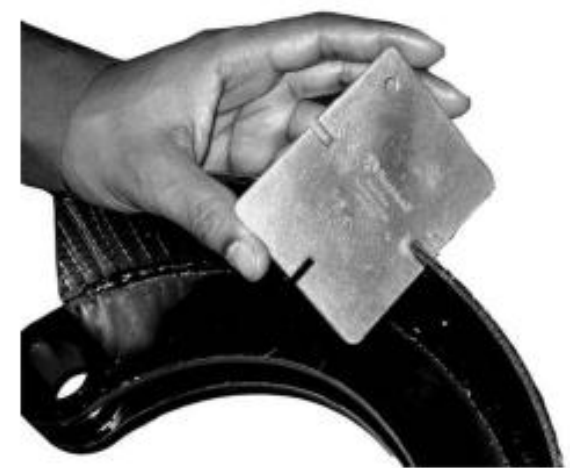

Tabel 3: Recommended shoe dimension for stemped steel shoe

\begin{tabular}{|l|c|}
\hline \multicolumn{2}{|c|}{ Minimum shoe table thickness } \\
\hline Type & Dimension (inches) \\
\hline S-Cam Q Plus & 0.171 \\
\hline S-Cam W Brake & 0.186 \\
\hline Wedge RDS & 0.216 \\
\hline
\end{tabular}

Gambar 14. Mengechek ketebalan brake shoe

6) Pengecekan Kelonggaran Lubang Keling (lihat Gambar 15)

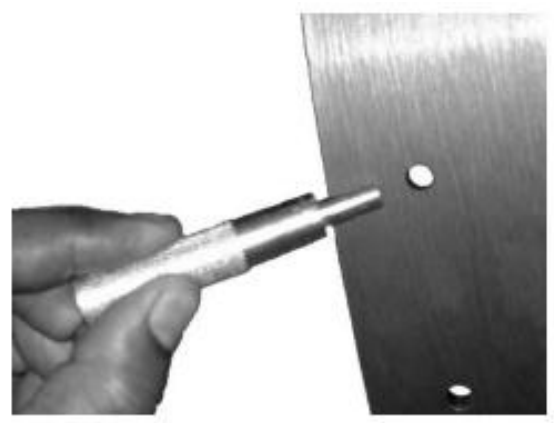

Gauge harus fit pada lubang paku keling. Apabila terasa longgar, ganti brake shoe.

Gambar 15. Mengechek kelonggaran lubang keling

7) Pengecekan Keretakan Las Antara Table dan Web (lihat Gambar 16)

Prosedurnya dilakukan secara visual dan bila ditemukan keretakan segera ganti brake shoe

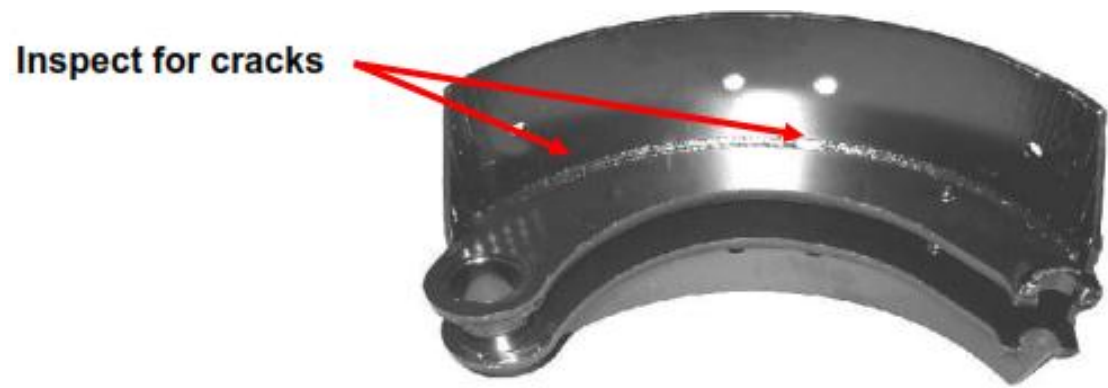

Gambar 16. Mengechek kondisi las pada brake shoe 
8) Pengecekan Dudukan Roller dan Kondisi Roller (lihat Gambar 17)

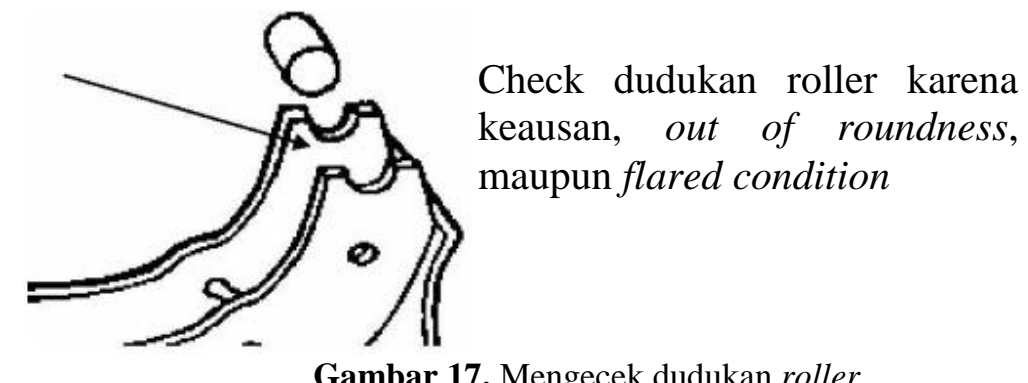

Gambar 17. Mengecek dudukan roller

9) Pengecekan Kondisi Engsel/Pin Pegas Pengembali

Check pin pegas pengembali karena keausan, rusak, atau longgar. Apabila pin hilang atau lonngar, check lubanglubangnya dengan pin baru. Ganti brake shoe apabila pin baru ternyata juga masih longgar.

\section{PEMASANGAN KAMPAS REM BARU}

Setelah tidak terdapat kecacatan/kerusakan brake shoe, tahapan selanjutnya adalah mengechek brake block, prosedur pengencangan brake block, perakitan akhir, dan inspeksi akhir.

1) Pengecekan brake block

Check brake block secara visual terhadap keretakan, geram, dan sudut-sudut tajam seperti pada Gambar 18. Permukaan shoe table seyogyanya bersih dan bebas dari material asing. Brake block yang terlihat tanda-tanda keretakan/rusak sebaiknya tidak digunakan.

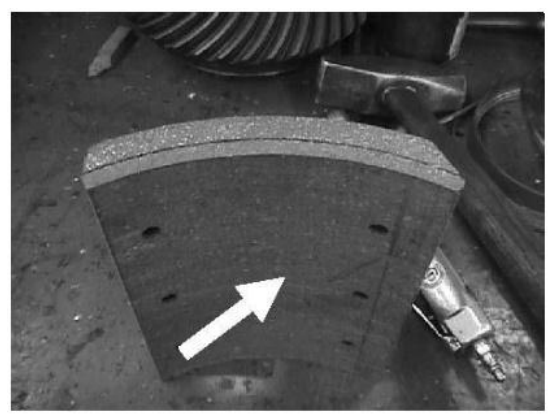

Gambar 18. Pengechekan brake block

2) Prosedur Pengencangan brake block

a) Tentukan panjang paku keling (lihat Tabel 4)

Tabel 5. Contoh perhitungan panjang paku keling

\begin{tabular}{|c|c|}
\hline Combined material thickness & .500 \\
\hline Clinch allowance $(1 / 4$ inch) & +.162 \\
\hline Rivet length & $.662=11 / 16$ inch long \\
\hline
\end{tabular}

b) Urutan pengencangan paku keling (lihat Gambar 19)

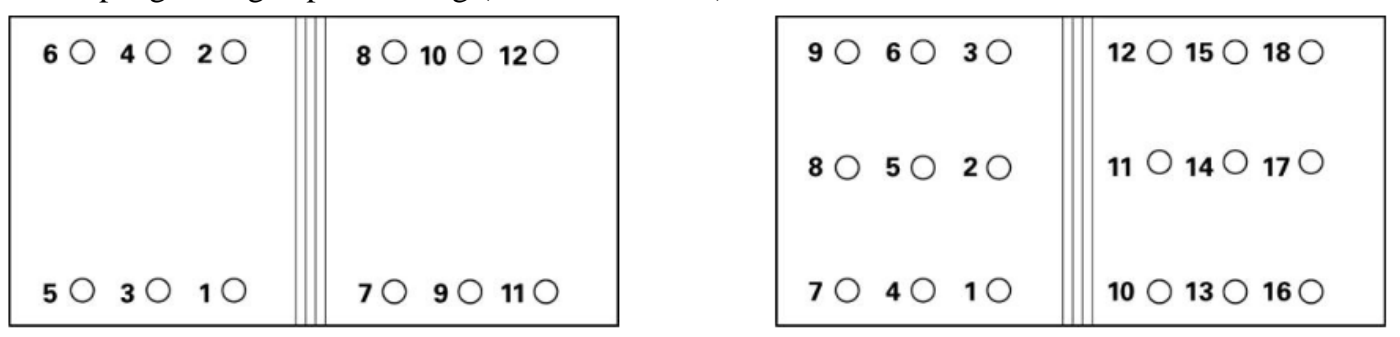

Gambar 19. Urutan pengencangan paku keeling dengan 12 atau 16 lubang

c) Kualitas pemasangan paku keeling yang memenuhi standard (lihat Gambar 20) 


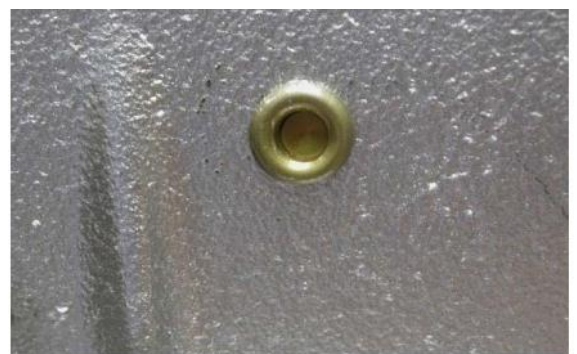

Gambar 20. Hasil pemasangan paku keling yang memenuhi standard

3) Perakitan Akhir

Lumasi dan pasang roller pada saat pemasangan brake shoe untuk mencegah kontaminasi.

4) Inspeksi Akhir (lihat Gambar 21)

a) Gunakan feeler gauge untuk mengukur sisi terluar antara shoe table dan brake block

b) Gap maksimum sebesar 0.010 inch antara sepatu (shoe) dengan linings sepanjang sisi-sisi dan ujung-ujung rakitan masih bisa diterima, dimana gap sebesar 0.025 inch pada web brake block baja masih diijinkan.

c) Lakukan pengechekan visual dang anti block bila terdapat keretakan

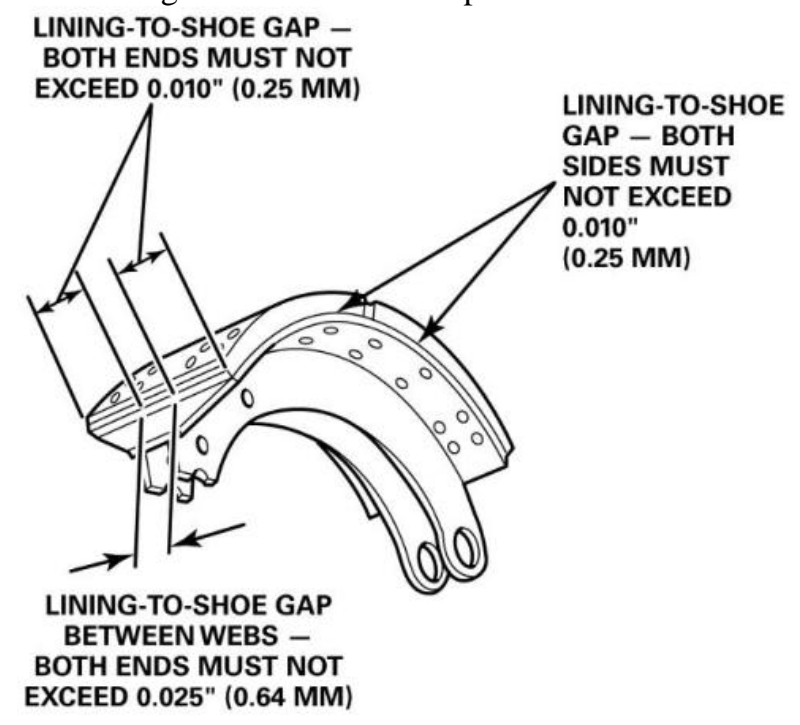

Gambar 21. Pengukuran gap brake shoe dan brake block

\section{KESIMPULAN}

1) Hasil uji kekuatan keling dan kampas rem menunjukkan keling yang berjumlah 8 buah mampu menahan beban geser maksimum pada kampas rem sebesar $1640.25 \mathrm{kN}$ atau 1/3 dari batas kemampuan keling menerima beban geser.

2) Prosedur pemeriksaan/pengechekan brake shoe (rangka rem) sangat penting untuk mencegah berkurangnya unjuk kerja dan terjadinya kegagalan fungsi pengereman karena brake shoe rusak/retak.

3) Pemasangan kampas rem yang tidak "duduk" dengan rata pada brake shoe (properly mate with the shoe table) dapat menyebabkan kampas rem retak selama pemakaian.

4) Dari SOP rebuild kampas rem nampak bahwa umur kampas rem (karena aus atau rusak) tidak semata-mata disebabkan oleh kualitas kampas rem, tetapi juga karena brake shoe yang retak/rusak tidak segera diganti dan kualitas pemasangan paku keling yang tidak standard.

5) Pencatatan setiap dilakukan penggantian kampas rem baru penting untuk mengetahui umur kampas rem karena : kualitas kampas rem, perilaku pengemudi, dan umur brake shoe.

\section{DAFTAR PUSTAKA}

1. Sinaga, Nazarudin, Wibowo, Dwi Basuki, 2006-2007, “Customer Relationship Program (CRP) Pelumas Industri Jawa Tengah", Laporan Proyek Kerja Sama PERTAMINA UPPDN IV Semarang dengan PUSLIT Pengembangan Teknologi (BANGTEK) UNDIP, Semarang

2. Sinaga, Nazarudin, Wibowo, Dwi Basuki, 2008, “Customer Maintain Program (CMP) Pelumas Industri Jawa Timur", Laporan Proyek Kerja Sama PERTAMINA UPPDN V Surabaya dengan PUSLIT Pengembangan Teknologi (BANGTEK) UNDIP, Surabaya

3. APTA BTS-SS-RP-003-07, 2007, "Recommended Practice for Transit Bis Brake Shoe Rebuild", The American Public Transportation Association, Washington DC 
4. Kementerian Perhubungan, 2009, "Transportation Statistic", Jakarta

5. BPS - Data Statistik Transportasi, http://www.bps.go.id/tab_sub/view.php?tabel=1\&daftar=1\&id_subyek=17\&notab=12

6. Neys, Adriaan, 2012, "In-Vehicle Brake System Temperature Model", Chalmers University of Technology, Sweden

7. Komite Nasional Keselamatan Transportasi (KNKT), November 2007, “Ringkasan Hasil Investigasi Kecelakaan Transportasi Lalu Lintas Angkutan Jalan Tahun 2007”, Departemen Perhubungan, Jakarta

8. Limpert, Rudolf, 1992, “Brake Design and Safety”, Society of Automotive Engineers, Inc., 400 Commonwealth Drive, Warrendale

9. Budynass and Nisbet, 2006, "Shigley's Mechanical Engineering Design", 8 ${ }^{\text {th }}$ Edition, The McGraw-Hill Companies, Inc.

10. Standar Nasional Indonesia (SNI), 2015, Laboratorium Balai Besar dan Bahan Teknik, Masa berlaku 13 Januari 2011 s/d 12 Januari 2015

11. OEM Standard Bis Mercedes OM 366 LA.II/23

12. Balotin, Jean Greselle, et.al, 2010, "Analysis of The Influence of Temperature on The Friction Coefficien of Friction Materials", ABCM Symposium Series in Mechatronics, Vol 4 pp. 898-906

13. ASTM Standard 2004 Volume $01-06$

14. North Carolina Department of Public Instruction School Support Division, March 2011, "Vehicle Preventive Maintanance School Bis Inspections", NC Bis Fleet: North Carolina School Transportation Fleet Manual, North Carolina

15. APTA BT-RP-001-05, 2005, "Recommended Practice for Transit Bis In-Service Brake System Performance Testing", The American Public Transportation Association, Washington DC

16. Frasle, Product Catalog - Friction Materials

17. Wirabuana, Ryan Patra, Wibowo, Dwi Basuki, 2014, “Analisis Kekuatan Paku Keling Pada Sub-Assembly Kampas Rem Bus", Laporan Tugas Akhir S-1, Jurusan Teknik Mesin UNDIP, Semarang

18. FMVSS No. 116, February 2010, "Federal Register - Proposed Rules", Federal Motor Vehicle Safety Standard, Vol. 75 No. 22, Washington DC 